\title{
Announcement and Call for Papers
}

\author{
EUROMECH \\ 3rd European Fluid Mechanics Conference \\ 15 - 18 September, 1997, Göttingen, Germany
}

This is the third meeting in a series launched by the European Mechanics Council (EUROMECH). The Council has entrusted the general planning of this series of conferences to the Fluid Mechanics Conference Committee, the current membership of which is given below. The membership of the Local Organizing Committee responsible for this third conference is also shown.

The Conference will be open to all those interested. The scientific sessions will be held in the Central Auditorium Building (Zentrales Horsaalgebaude, ZHG) of the University of Gorttingen. In addition a programme for accompanying persons will be organized. The conference office will be open from 14 to 18 September, 1997.

President of.EUROMECH: Prof. D.G. Crighton, DAMTP, University of Cambridge, Silver Street, Cambridge, CB3 9FW, England.

Secretary General: $\quad$ Prof. R. Lundberg, School of Engineering, Uppsala University, Box 534, S-75171 Uppsala, Sweden

Treasurer:

Prof. E.-A. Muller, Inst. F. Angewandte Mech. und-Stromungsphysik, Bunsenstrasse 10 , Gottingen

\section{PROGRAMME}

1997 EUROMECH Fluid Mechanics Lecture (1 hour)

U. Frisch (Nice) - Towards a theory of intermittency

Expository Review Lectures (45 minutes)

H. Alfredsson (Stockholm) - Free stream turbulence and transient growth in boundary layer flows

P. Clavin (Marseille) - Dynamics of combustion waves in gases

M. Germano (Turin) - Modelling of turbulent flows: the notion of the average

$\mathrm{R}$. Hillier (London) - Hypersonic viscous flows: an integration of experiment and CFL

W. Lauterborn (Gottingen) - News from cavitation bubble dynamics

A. Maslov (Novosibirsk) - Experimental study of instability processes in hypersonic boundary layers

$\mathrm{T}$. Maxworthy (Los Angeles) - convectively-driven geophysical flows

T. Pedley (Cambridge) - Time-dependent flow-structure interactions in biomechanics

Agterov - The chemical engineering approach to mixing and reaction in process flow systems

L. v. Wijngaarden (Enschede) - The collective behaviour of air bubbles rising in water.

Evening Lecture (this lecture is open to the public)

I. Rehberg (Magdeburg) - Granular matter: shaken, not stirred. And very dry (with experiments)

Mini-symposia (duration about half a day)

Turbulent mixing - mechanisms and control

Dispersed multiphase flows

Convener: H. Fiedler (Berlin)

Forced flows with solidification

Convener: M. Sommerfeld (Halle)

Convener: W. Schneider (Vienna)

\section{CONTRIBUTED PAPERS}

Contributed papers will be presented in parallel oral sessions. There will be long (20 minutes including discussion) and short (10 minutes including discussion) presentations. In addition, these papers may also 
be displayed as posters. Selection of papers will be made on the basis of an abstract of one page of A4 paper only, including pictures (the characters not smaller than $2.9 \mathrm{~mm}$ ). Participants submitting a contributed paper should send one copy of their abstract, indicating the preferred form of presentation (10/20 minutes; poster yes/no) to the Local Organizing Committee.

\section{REGISTRATION FEE}

The Conference registration fee will be $300 \mathrm{DM}$ for members of the European mechanics Society, 360 DM for non-members and $90 \mathrm{DM}$ for accompanying persons. The conference banquet and refreshments during the conference breaks (coffee, tea, etc.) are included in these fees. Fees paid after 16 May, 1997 will be $350 \mathrm{DM}$ for members and $410 \mathrm{DM}$ for non-members. Luncheon will be available during the conference at the ZHG at a cost of approximately $7 \mathrm{DM}$.

\section{FINANCIAL SUPPORT}

The Local Organizing Committee expects to have a limited amount of money at its disposal for partial reimbursements to participants unable to recover the cost of participation from sources in their own countries. Priority will be given to the needs of participants from eastern Europe and young scientists.

\section{ACCOMMODATION}

Information concerning accommodation and transportation will be given in our next announcement. Moderately priced accommodation will be available for younger scientists.

\section{COMMITTEES}

\begin{tabular}{|c|c|}
\hline Fluid Mechanics Conference Committee & Local Organizing Committee \\
\hline $\begin{array}{l}\text { D.G. Crighton (Cambridge) } \\
\text { R. Dvorak (Prague) } \\
\text { H.H. Fernholz (Berlin) (chairman) } \\
\text { E.J. Hopfinger (Grenoble) } \\
\text { G.E.A. Meier (Gottingen) } \\
\text { P.A. Monkewitz (Lausanne } \\
\text { E.-A. Maller (Gottingen) } \\
\text { F.T.M. Nieuwstadt (Delf) } \\
\text { T.J. Pedley (Cambridge) } \\
\text { L.R. Piva (Rome) } \\
\text { W. Schneider (Vienne) } \\
\text { L. van Wijngaarden (Enschede) }\end{array}$ & $\begin{array}{l}\text { A. Dankelacker } \\
\text { H. Eckelmann (Co-Chairman) } \\
\text { W. Kordulla } \\
\text { G.E.A. Meier (Chairman) } \\
\text { W. Mohring } \\
\text { E.-A. Maller } \\
\text { D. Ronneberger (Co-Chairman) } \\
\text { Chr. Voigt (Scientific Secretary) }\end{array}$ \\
\hline $\begin{array}{l}\text { Chairman of EFMC97: } \\
\text { Prof. Dr. G.E.A. Meier } \\
\text { Institut fur Stromungsmechanik } \\
\text { Bunsenstrasse } 10 \\
\text { D-37073 Gottingen, Germany } \\
\text { Tel: +49551709 } 2177 \\
\text { Fax: +49 551709 } 2889 \\
\text { e-mail: GEAM@ES.GO.DLR.DE }\end{array}$ & $\begin{array}{l}\text { ing Address for contributed papers: } \\
\text { Christoph Volgt } \\
\text { F. Angewandte Mechanik und Stromungsphysik } \\
\text { ersitat Gottingen, Bunsenstrasse } 10 \\
073 \text { Gottingen, Germany } \\
+495515176547 \\
\text { +49551709 2595 /+495515176595 } \\
\text { iil: EFMC97@MSFD1.GWDG.DE }\end{array}$ \\
\hline
\end{tabular}


The European Mechanics Society is a non-profit organization for the promotion of the science of mechanics in Europe. Detailed information on the Society and forms for the application of membership can be obtained at the registration of all EUROMECH colloquia and conferences or from the President, the Secretary General or the Treasurer. The annual membership fee is $45 \mathrm{DM}$, reduced for members of the affiliated organizations of EUROMECH (AIMETA [Italy], AUM [France], BYELOMECH [Byelorussia], CCEMS [Czech Republic], GAMM [Germany], USME [Ukraine]).

Information about the conference can also be obtained from our WWW-page at: http://msfm42.gwdg.de/efmc97/ 